\title{
JIGSAW LEARNING UNTUK MENINGKATKAN KEMAMPUAN BERKOMUNIKASI VERBAL DAN HASIL BELAJAR PENDIDIKAN AGAMA ISLAM
}

\author{
FUTIHATUN \\ SMK Negeri 1 Depok Sleman D.I Yogyakarta \\ Email : futihatun23@guru.smk.belajar.id
}

\begin{abstract}
ABSTRAK
Penelitian tindakan kelas ini bertujuan untuk meningkatkan hasil belajar Pendidikan Agama Islam dan Budi Pekerti serta kemampuan berkomunikasi verbal pada peserta melalui penerapan jigsaw learning. Penelitian dilaksanakan di kelas X OTKP 1 SMK N 1 Depok dalam 2 siklus. Setiap siklus meliputi tahapan perencanaan, pelaksanaan tindakan, refleksi. Pengumpulan data kemampuan berkomunikasi verbal melalui observasi, meliputi menjelaskan materi, bertanya, menjawab pertanyaan, berpendapat, dan berdiskusi. Data hasil belajar berupa nilai pre-test dan pos-test setiap siklus. Data yang diperoleh dianalisa secara kualitatif dalam bentuk persentase. Hasil penelitian menunjukkan adanya peningkatkan kemampuan berkomunikasi verbal dan prestasi belajar Pendidikan Agama Islam dan Budi Pekerti peserta didik setelah penerapan pembelajaran dengan jigsaw learning . Peningkatan ini nampak pada hasil observasi, pre-test maupun pos test pada tindakan siklus I, dan siklus II. Data perkembangan peningkatan kemampuan berkomunikasi verbal peserta didik dapat dilihat dari rata-rata keaktifan peserta didik pada masing-masing siklus, yakni dari $16,11 \%$ menjadi $46,67 \%$. Prestasi hasil belajar juga mengalami peningkatan, pada siklus 1 rata-rata hasil belajar 74,31 menjadi 85,97 pada siklus 2. Persentase ketuntasan belajar juga mengalami peningkatan dari 55,56\% pada siklus 1 menjadi $86,11 \%$ pada siklus II.
\end{abstract}

Kata kunci : Jigsaw Learning, Komunikasi Verbal, Hasil Belajar

\section{PENDAHULUAN}

Pendidikan Agama Islam dan Budi Pekerti di sekolah bertujuan menumbuh kembangkan keimanan dan ketaqwaan kepada Allah SWT., serta akhlak mulia peserta didik. Jika selama ini Pendidikan Agama Islam dan Budi Pekerti di sekolah didominasi oleh pendekatan doktriner, ideologis dan hanya terhenti pada aspek kognitif, maka perlu diubah dengan pendekatan ilmu (rasional), iman dan amal (kognitif, afektif dan psikomotor). Pendidikan Agama Islam di sekolah harus dapat memotivasi peserta didik untuk mengembangkan keilmuan, memperkuat keimanan dan dapat dijadikan landasan moral dalam kehidupan sehari-hari (Sutrisno, 2008: 79)

Pada realitasnya pembelajaran Pendidikan Agama Islam dan Budi Pekerti masih sering berorientasi pada buku sebagai sumber referensi yang utama sehingga lebih bersifat tekstual. Penyampaian materi lebih dominan menggunakan metode ceramah. Akibatnya pembelajaran menjadi monoton, kurang menarik, membosankan, pasif, kurang mengeksplor kemampuan peserta didik. Begitu pula di SMK Negeri 1 Depok, khususnya kelas X OTKP (Otomatisasi Tata Kelola Perkantoran) 1 dalam proses belajar mengajar Pendidikan Agama Islam dan Budi Pekerti (PAI dan BP), pada umumnya peserta didik bersikap pasif, kurang berminat dalam bertanya, tidak mau menjawab pertanyaan yang disampaikan oleh guru PAI dan BP, jarang mengajukan pendapat, bahkan dalam berdiskusi. Proses belajar mengajar hanya didominasi oleh guru dan beberapa peserta didik yang pandai dan berani mengemukakan pendapat. Hasil belajar PAI dan BP secara umum belum mencapai ketuntasan secara klasikal, nilai SKM (Skor Ketuntasan Minimal) yang telah ditentukan oleh guru sebesar 75.

Hal ini menunjukkan bahwa dalam proses belajar mengajar PAI dan BP, guru masih berfokus pada penguasaan materi pelajaran, sehingga kurang memperhatikan nilai afektif dan psikomotorik peserta didik. Dengan demikian sistem dan cara pembelajaran yang dilakukan oleh guru kurang mendukung terciptanya aktivitas serta keterlibatan peserta didik secara 
langsung. Hal ini, mendorong penulis untuk menerapkan jigsaw learning sebagai upaya meningkatkan kecakapan komunikasi verbal peserta didik dalam proses belajar mengajar, menempatkan peserta didik sebagai subjek belajar bukan sebagai objek belajar, dengan harapan kualitas proses pembelajaran maupun hasil belajar mencapai hasil yang optimal.

Kemampuan komunikasi verbal penting dikuasai oleh peserta didik di SMK terutama jurusan OTKP, karena selain menunjang tumbuh-kembangnya ke masa dewasa, keterampilan komunikasi seperti jurnalistik (menulis) dan public speaking (berbicara di depan umum) banyak dibutuhkan dalam bidang pekerjaan, bahkan bisa menjadi profesi tersendiri nantinya. Kemampuan komunikasi verbal juga dibutuhkan dalam pengembangan usaha, pengembangan dan pemberdayaan diri menuju kesuksesan sebagai lulusan SMK jurusan OTKP. Peserta didik yang mempunyai kemampuan komunikasi verbal yang baik, akan baik pula hasil belajarnya . Penelitian ini bertujuan untuk mengetahui peningkatan kemampuan komunikasi verbal dan hasil belajar peserta didik dengan penerapan model pembelajaran jigsaw learning.

\section{METODE PENELITIAN}

Penelitian ini merupakan penelitian tindakan kelas yang dilaksanakan padan bulan Januari s.d Maret. Subyek penelitian ini adalah peserta didik kelas X OTKP 1 SMK N 1 Depok tahun pelajaran 2019/2020 terdiri atas 36, dengan jenis kelamin wanita semua. Keadaan peserta didik kelas ini sangat beragam, dari segi kemampuan komunikasi verbal maupun hasil belajarnya ada yang sangat menonjol dan ada sebagian peserta didik yang lambat/ kurang .

Pelaksanaan penelitian dalam 2 siklus. Setiap siklus terdiri dari 2 kali pertemuan. Setiap pertemuan 3x45 menit dengan langkah-langkah perencanaan, pelaksanaan tindakan, pengamatan dan diakhir siklus dilakukan refleksi. Pengumpulan data bersumber pada perangkat instrument penelitian, yakni lembar observasi peserta didik untuk mengetahui kemampuan komunikasi verbal, dan soal pre-test serta post-tes untuk mengetahui hasil belajar.

Data kemampuan berkomunikasi verbal dianalisa secara deskriptif dalam bentuk persentase. Gejala yang diamati diberi skor, kemudian dibandingkan dengan jumlah skor maksimal yang diharapkan sehingga diperoleh persentase. Data hasil belajar berupa nilai pre-test dan post-tes dianalisa dengan mencari skor rata-rata yang diperoleh dan ketuntasan belajar kelas yang dicapai.

\section{HASIL DAN PEMBAHASAN}

Desain penelitian yang dikembangkan dalam penelitian tindakan kelas ini adalah desain yang diadaptasi dari Kemmis dan Taggart (Raka Joni, dkk, 1998), yang menggambarkan bahwa penelitian tindakan dilaksanakan dalam beberapa siklus dan setiap siklus terdiri atas 4 tahap, yaitu: perencanaan (planning), pelaksanaan tindakan (action), observasi (observation), dan refleksi (reflektion).

\section{A. SIKLUS I}

Hasil penelitian berupa rekapitulasi skor hasil pengamatan kemampuan berkomunikasi verbal pada proses pembelajaran dan hasil belajar berupa nilai pre-test, post-test peserta didik pada materi Alquran dan Hadis dengan kegiatan menganalisis dan mengevaluasi makna Q.S. Luqman/31: 13-14 dan Q.S. Al-Baqarah/2: 83, serta Hadis tentang kewajiban beribadah dan bersyukur kepada Allah serta berbuat baik kepada sesama manusia, pada siklus 1 diperoleh melalu tahap:

1. Perencanaan Tindakan

1) Siklus pertama dilaksanakan dalam 2 kali tatap muka ( $3 \times 45$ menit). Pertemuan pertama. menganalisis dan mengevaluasi makna Q.S. Luqman/31: 13-14. Pertemuan kedua presentasi hasi diskusi tentang analisis dan evaluasi makna Q.S. Luqman/31: 1314.

2) Menyusun instrumen pembelajaran antara lain: sekenario pembelajaran (RPP), soal pretest dan post-test. 
3) Skenario pembelajaran disusun sesuai materi dan teknik pembelajaran yang digunakan, yakni jigsaw learning.

Teknik pembelajaran jigsaw termasuk dalam model pembelajaran kooperatif. Menurut Slavin (2007) pembelajaran kooperatif menggalakkan siswa berinteraksi secara aktif dan positif dalam kelompok. Langkah-langkah Teknik Pembelajaran Jigsaw (Jihan Nabila, 2015) adalah sebagai berikut: (1) Mengamati. Guru memberikan penjelasan secara garis besar materi. Penjelasan dapat dilakukan melalui video, rekaman, slides, atau materi print out. (2) Menanya.Guru memberikan kesempatan kepada peserta didik untuk bertanya tentang materi yang ia dapatkan dari langkah sebelumnya. (3) Eksplorasi. Guru membagi peserta didik menjadi beberapa kelompok ( kelompok asal dan kelompok ahli). Setiap kelompok diberikan materi yang berbeda untuk dipelajari dan didalami. (4) Asosiasi. Setelah selesai mempelajari dan mendalami materi, peserta didik diminta untuk membentuk kelompok baru yang masing-masing beranggotakan peserta didik yang berasal dari kelompok yang berbeda sebelumnya. Misalnya: pertama dibentuk kelompok A B C D. Kelompok baru yang dibentuk harus beraggotakan peserta didik yang berasal dari kelompok A B C D. Setiap peserta didik menyampaikan materi yang dipelajari dari kelompok sebelumnya sehingga terjadi sharing materi antar peserta didik dalam kelompok baru. (5) Komunikasi. Guru meminta perwakilan setiap kelompok untuk menyampaikan apa yang peserta didik dapatkan dan pelajari. Guru membimbing, mengapresiasi dan melakukan refleksi terhadap pekerjaan peserta didik.

4) Menyusun instrumen observasi peserta didik

\section{Pelaksanaan Tindakan}

1) Langkah awal dalam pelaksanaan tindakan adalah dilaksanakannya pre-test untuk mengetahui kemampuan awal tentang analisis dan makna Q.S. Luqman/31: 13-14

2) Guru melaksanakan pembelajaran sesuai dengan sekenario pembelajaran yang telah direncanakan yaitu penerapan teknik pembelajaran jigsaw.

3) Guru membagi peserta didik menjadi 6 kelompok dengan anggota masing-masing kelompok berjumlah 6 peserta didik. Pembagian kelompok dilakukan dengan berhitung, mulai dari nomor satu sampai enam. Peserta didik yang menyebutkan angka yang sama menjadi satu kelompok.

4) Guru menugaskan kepada masing-masing kelompok untuk mempelajari tema yang diberikan dengan menggunakan referensi buku paket PAI kelas X, modul PAI kelas X, Tafsir Al-Qur'an, dan berbagai sumber dari internet.

5) Setelah selesai mempelajar tema yang telah diberikan oleh guru dalam kelompok asal, tiap anggota kelompok yang mempelajari tema yang sama bertemu dalam kelompok baru (kelompok ahli) untuk berdiskusi, bertukar pendapat, saling bertanya jawab tentang materi yang sudah dipelajarinya.sehingga peserta didik mendapatkan pengetahuan dan wawasan yang lebih lengkap dan dalam.

\section{Observasi}

1) Untuk mengetahui kemampuan berkomunikasi verbal, peneliti melakukan pengamatan dalam menjelaskan materi,menjawab pertanyaan, berdiskusi, menyampaikan pendapat, mengajukan pertanyaan, dengan menggunakan lembar observasi peserta didik.

2) Data deskripsi tentang hal-hal khusus selama kegiatan pembelajaran pada siklus pertama: Peserta didik lebih bersemangat dan bersungguh-sungguh, kerja sama antar anggota kelompok tampak meningkat, aktifitas pembelajaran lebih demokratis, guru melaksanakan pembelajaran sesuai dengan rencana waktu yang tersedia, guru telah melaksanakan kegiatan pembelajaran sesuai dengan skenario pembelajaran yang telah direncanakan. 


\section{Refleksi}

Dari hasil observasi dapat disimpukan dari 36 peserta didik yang aktif menjelaskan materi sebanyak $13,89 \%$ peserta didik, aktif dalam berdiskusi sebanyak $27,78 \%$ peserta didik, aktif mengeluarkan pendapat sebanyak 5,56\% peserta didik, aktif bertanya sebanyak 13,89\% peserta didik, dan aktif menjawab pertanyaan $19,44 \%$ peserta didik. Sedang nilai hasil pre-test rata-rata 65,69 dengan ketuntasan $27,78 \%$, dan nilai post-test rata-rata 74,31 dengan ketuntasan $55,56 \%$.

Berdasarkan hasil refleksi di atas, diketahui bahwasanya rata-rata kemampuan komunikasi verbal peserta didik hanya $16,11 \%$, masih jauh dari yang diharapkan, demikian juga rata-rata hasil peserta didik belum mencapai skor ketuntasan minimal (SKM). Maka dari itu peneliti merencanakan untuk melanjutkan penelitian ini pada siklus kedua, dengan harapan pencapaian kemampuan komunikasi verbal dan hasil belajar peserta didik dapat mencapai atau melampaui SKM.

\section{B. SIKLUS II}

1. Perencanaan Tindakan

Siklus kedua dilaksanakan dalam dua kali tatap muka (6 x 45 menit) masih dengan kompetensi Al-Qur" an dengan materi menganalisis dan mengevaluasi makna Q.S. AlBaqarah/2: 83. Pertemuan ketiga menganalisis dan mengevaluasi makna Q.S. Al-Baqarah/2: 83 keempat presentasi hasi diskusi tentang analisis dan evaluasi makna Q.S. Al-Baqarah/2: 83 Langkah-langkah perencanaan dalam siklus kedua ini adalah

1) Menyusun sekenario pembelajaran sebagaimana pada siklus I

2) Menyiapkan lembar observasi peserta didik.

\section{Pelaksanaan Tindakan}

1) Guru melaksanakan pembelajaran sesuai dengan sekenario (RPP).

2) Guru mempersilahkan peserta didik untuk mengatur tempat duduk sesuai dengan kelompok asal yang telah dibentuk pada pertemuan pertama/siklus 1 .

3) Peserta didik yang telah mendapatkan penjelasan, mendalami dan mendiskusikan pada kelompok ahli, mentransformasikan pengetahuan dan informasi kepada yang telah didapat kepada kelompok asal. Guru memberikan bimbingan bagi peserta didik/kelompok yang membutuhkan.

4) Tiap peserta didik/kelompok ahli mempresentasikan hasil diskusi.

5) Guru mengklarifikasi hasil diskusi kelas, dan memberikan penekanan-penekanan sehingga tidak terjadi miskomunikasi pada diri peserta didik.

6) Selama proses pembelajaran berlangsung aktifitas peserta didik diamati oleh guru.

7) Guru memberikan post-test pada akhir siklus.

\section{Observasi}

Untuk mengetahui kemampuan berkomunikasi verbal, dilakukan pengamatan oleh guru, bagaimana peserta didik menjelaskan materi, menjawab pertanyaan, berdiskusi, menyampaikan pendapat, mengajukan pertanyaan, dengan menggunakan lembar observasi peserta didik. Data deskripsi tentang hal-hal khusus selama kegiatan pembelajaran pada siklus kedua diketahui peserta didik lebih bersemangat dan bersungguh-sungguh, kerja sama antar anggota kelompok tampak meningkat, aktifitas pembelajaran lebih demokratis dan tidak lagi didominasi guru dan peserta didik yang pandai, guru melaksanakan pembelajaran sesuai dengan rencana waktu yang tersedia, guru telah melaksanakan kegiatan pembelajaran sesuai dengan sekenario pembelajaran yang telah direncanakan.

\section{Refleksi}

Dari hasil observasi dengan menggunakan lembar observasi peserta didik saat berdiskusi dalam kelompok diperoleh data sebagai berikut: jumlah peserta didik yang aktif 
menjelaskan materi 55,56\%, aktif dalam berdiskusi 55,56\%, aktif berpendapat, 22,22\%, aktif bertanya, 55,56\%, dan aktif menjawab pertanyaan $44,44 \%$. Rata-rata kemampuan berkomunikasi verbal sebesar $46,67 \%$. Sedangkan nilai post-test rata-rata 85,97 dengan ketuntasan $86,11 \%$.

Berdasar data yang ada dan perbandingan antara siklus I dan siklus II, dapat disimpulkan bahwa pembelajaran dengan menerapkan tipe jigsaw pada peserta didik kelas $\mathrm{X}$ OTKP 2 SMK Negeri 1 Depok dapat meningkatkan kemampuan berkomunikasi verbal dan meningkatkan hasil belajar Pendidikan Agama Islam dan Budi Pekerti.

\section{Pembahasan}

Penelitian sebelumnya, yang dilakukan oleh Afifudin Alfaris (2014) yang membandingkan antara hasil belajar kelas yang menerapkan pembelajaran jigsaw dengan kelas konvensional diperoleh hasil sebagai berikut: pada perhitungan uji $\mathrm{t}$, ditemukan nilai $\mathrm{t}=1,466$ derajat signifikansi $5 \%$ dengan $\mathrm{db}=60-2=58$, dan $\mathrm{t}$ tabel $=2,002$. Berdasar perhitungan tersebut menunjukan bahwa ada perbedaan antara kelas yang menggunakan model pembelajaran kooperatif Jigsaw dengan kelas yang menggunakan model pembelajaran konvensional, sebab t hitung 1,466 lebih kecil dari t tabel 2,002.

Penelitian yang penulis lakukan tidak hanya meneliti ada tidaknya pengaruh jigsaw learning pada hasil belajar, namun juga kemampuan komunikasi verbal. Kemampuan komunikasi verbal peserta didik dapat dimunculkan dan dikembangkan melalui aktivitas pembelajaran yang dikendalikan oleh guru melalui model dan metode pembelajaran. Model dan metode pembelajaran yang dapat melatihkan keterampilan komunikasi peserta didik antara lain model pembelajaran kooperatif jigsaw (Vanalita, Jalmo, \& Marpaung, 2014). Jigsaw mampu meningkatkan kemampuan komunikasi verbal peserta didik melalui diskusi kelompok ahli dan kelompok asal yang dapat meningkatkan pemahaman peserta didik terhadap materi (Nurhaeni, 2011). Jigsaw melibatkan peserta didik untuk berinteraksi satu sama lain melalui kelompok ahli dan kelompok asal sehingga peserta didik terbiasa untuk aktif (Aryanti, 2015). Dari hasil analisi penelitian di lapangan kemampuan, berkomunikasi verbal pada siklus I dan II dapat digambarkan dalam gambar 1 berikut:

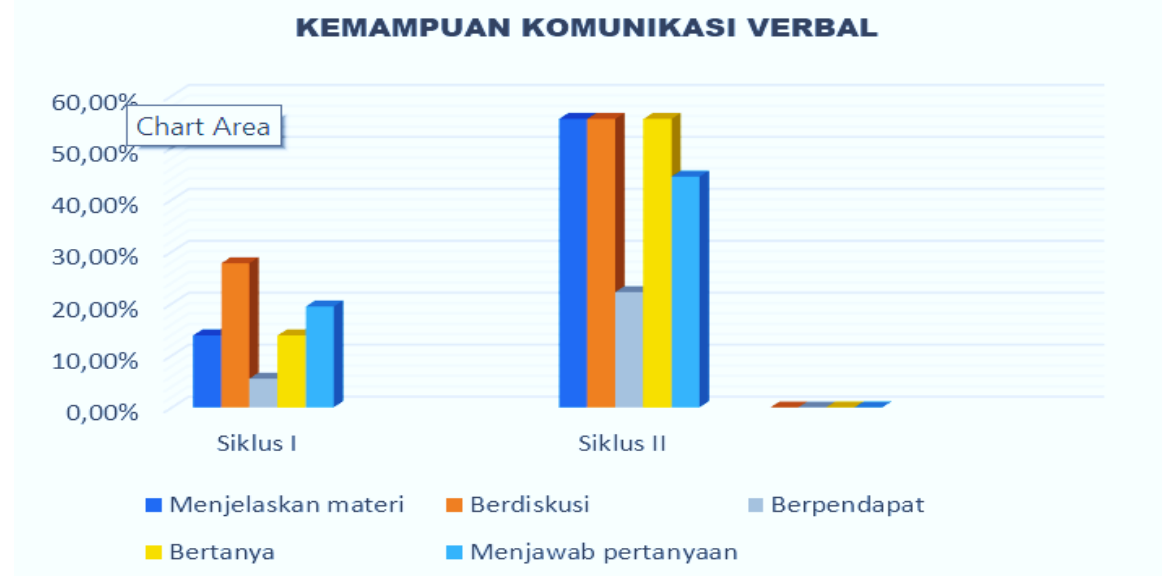

Gambar 1. Kemampuan Berkomunikasi Verbal Kelas X OTKP 2

Dari gambar 1 dapat dilihat bahwa kemampuan berkomunikasi verbal yang paling banyak adalah keaktifan dalam berdiskusi, baik di siklus ke-1 maupun siklus ke- 2. Keberanian dalam menjelaskan materi dan bertanya mengalami kenaikan yang cukup signifikan di siklus ke-2. Secara umum aspek-aspek yang diamati dalam kemampuan komunikasi verbal mengalami kenaikan pada siklus kedua. Dalam keaktifan menjelaskan materi belum semua peserta didik aktif, karena memang dibutuhkan pengetahuan, kemampuan dan keterampilan yang komplek. Keaktifan untuk bertanya dan menjawab pertanyaan telah banyak dibantu dari menjawab pertanyaan yang ada dalam diskusi kelompok ahli, sehingga tinggal membutuhkan 
motivasi untuk menjawab pertanyaan dalam diskusi kelompok asal. Sedangkan untuk keaktifan berupa mengajukan pendapat masih sedikit yang aktif meski sudah mengalami peningkatan di siklus kedua. Kemampuan berpendapat membutuhkan kemampuan mengatasi masalah beban psikologis pada diri peserta didik, kemampuan memunculkan ide-ide baru, dan pemahaman terhadap permasalahan yang dibahas.

Untuk mengukur adanya peningkatan hasil belajar, diadakan pre-test dan post-tes. Pretest dilaksanakan sebelum pembelajaran untuk mengetahui kemampuan awal peserta didik. Post-tes dilakukan setelah pembelajaran selesai dengan tujuan untuk mengetahui mengetahui keberhasilan proses pembelajaran dengan menggunakan jigsaw learning. Hasilnya dapat dilihat pada gambar 2 berikut:

\begin{tabular}{|c|c|c|c|c|c|}
\hline \multicolumn{7}{|c|}{ Tabel 1. Nilai Pre-test dan Post-test Siklus I } \\
\hline No & Nilai & Pretes & N. $\sum$ PD & Post-tes & N. $\sum$ PD \\
\hline 1 & 100 & - & 0 & 0 & 0 \\
\hline 2 & 95 & - & 0 & 4 & 380 \\
\hline 3 & 90 & - & 0 & 2 & 180 \\
\hline 4 & 85 & - & 0 & 3 & 255 \\
\hline 5 & 80 & 4 & 320 & 7 & 560 \\
\hline 6 & 75 & 6 & 450 & 4 & 300 \\
\hline 7 & 70 & 10 & 700 & 7 & 490 \\
\hline 8 & 65 & 2 & 130 & 3 & 195 \\
\hline 9 & 60 & 9 & 540 & 2 & 120 \\
\hline 10 & 55 & 1 & 55 & 1 & 55 \\
\hline 11 & 50 & 2 & 100 & 1 & 50 \\
\hline 13 & 45 & & 0 & 2 & 90 \\
\hline 14 & 40 & 1 & 40 & & 0 \\
\hline 15 & 35 & & 0 & & 0 \\
\hline Jumlah & 30 & 1 & 30 & & 0 \\
\hline
\end{tabular}

Dari gambar 2 diketahui adanya peningkatan hasil dari pre-test ke post-tes. Rata- rata nilai pre-test 65,69 (2365/36), meningkat menjadi 74,31 (2675/36). Pada pre-test 10 peserta didik yang sudah tuntas, meningkat menjadi 20 peserta didik setelah mengalami proses pembelajaran dengan jigsaw learning. SKM yang ditetapkan untuk kelas X pada mata pelajaran Pendidikan Agama dan Budi pekerti adalah 75 sedangkan nilai rata rata yang dicapai pada post-tes belum mencapai SKM, maka penelitian dilanjutkan pada siklus yang kedua dengan kompetensi yang sama yakni Al-Qur'an Q.S. Al-Baqarah/2: 83. 
Tabel 2. Nilai Pre-test dan Post-test Siklus II

\begin{tabular}{|r|c|c|c|c|c|}
\hline No & Nilai & Pretes & N. $\sum$ PD & Post-tes & N. $\sum$ PD \\
\hline 1 & 100 & 0 & 0 & 4 & 400 \\
\hline 2 & 95 & 0 & 0 & 8 & 760 \\
\hline 3 & 90 & 0 & 0 & 9 & 810 \\
\hline 4 & 85 & 1 & 0 & 4 & 340 \\
\hline 5 & 80 & 2 & 160 & 5 & 400 \\
\hline 6 & 75 & 5 & 375 & 1 & 75 \\
\hline 7 & 70 & 7 & 490 & 1 & 70 \\
\hline 8 & 65 & 10 & 650 & 2 & 130 \\
\hline 10 & 60 & 2 & 120 & 1 & 60 \\
\hline 11 & 55 & 0 & 0 & & 0 \\
\hline 12 & 40 & 6 & 300 & 1 & 50 \\
\hline 13 & 40 & 2 & 80 & & 0 \\
\hline 15 & 35 & 0 & 0 & & 0 \\
\hline Jumlah & 30 & 0 & 0 & & 0 \\
\hline
\end{tabular}

Pada siklus kedua diperoleh hasil pre-test terdapat 28 peserta didik yang belum tuntas, hasil pada post-tes 31 peserta didik mendapatkan ketuntasan dalam belajar. Hal ini menunjukkan keberhasilan pembelajaran dengan menggunakan jigsaw learning, karena yang tadinya hanya $22,22 \%$ peserta didik yang tuntas menjadi $86,11 \%$ tuntas. Rata-rata kelas pun mengalami kenaikan dari 61,67 menjadi 85,97.

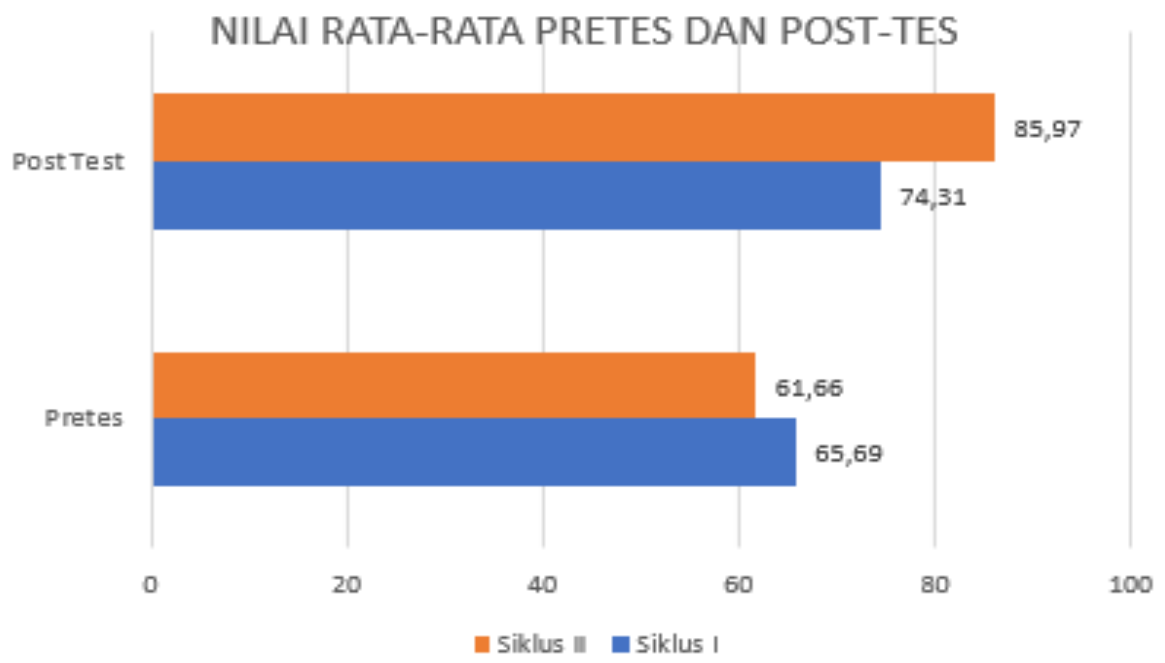

Gambar 2. Grafik Nilai Rata-Rata Pre-test dan Post-test

Apabila dibandingkan antara hasil penelitian pre- test dan post-tes siklus I maupun di di siklus II mengalami peningkatan rata-rata nilai. Antara nilai rata-rata post- test siklus I dan siklus II, rata rata post-tes siklus I , 74,31, siklus II 85,97, juga mengalami kenaikan, yakni sebesar 11,66 point. 


\section{KETUNTASAN BELAJAR}

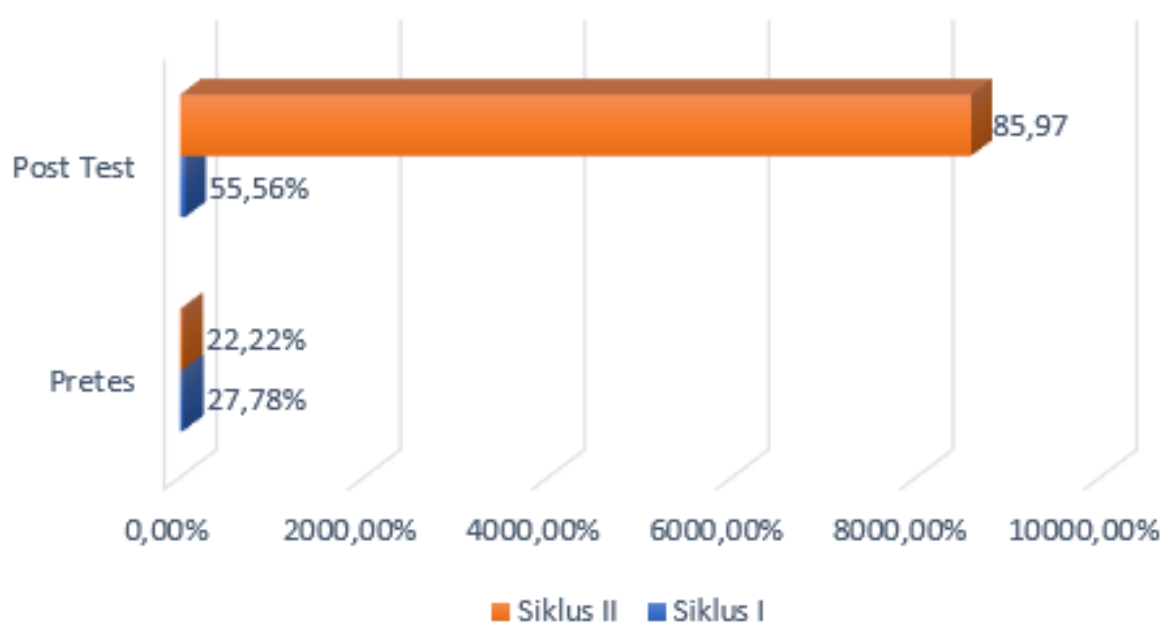

Gambar 3. Grafik Ketuntasan Belajar Hasil Pre-test dan Post-tes

Dari gambar 5, diperoleh hasil analisis nilai pre-test dan post-test pada siklus I nilai ketuntasan pre-test sebesar 27,78\%, ketuntasan post-test 55,56\%. Di siklus II ketuntasan pretest $22,22 \%$, post-test dengan ketuntasan $85,97 \%$. Ketuntasan belajar peserta didik meningkat dengan peran aktifnya dalam pembelajaran jigsaw learning.

Keterlibatan peserta didik dalam pembelajaran secara aktif akan mendorong kondisi belajar yang menyenangkan dan lebih bermakna. Sesuatu yang diperoleh dengan perasaan senang dan dengan kebermaknaan maka akan menguatkan kesan dalam memori peserta didik, sehingga akan meningkatkan hasil belajar yang dicapai.

\section{PENUTUP}

Dari hasil penelitian tindakan kelas yang telah dilaksanakan dengan menerapkan teknik pembelajaran jigsaw pada kompetensi Al-Qur'an di kelas X OTKP 1 SMK N 1 Depok diperoleh kesimpulan dapat meningkatkan kemampuan berkomunikasi verbal dan prestasi belajar Pendidikan Agama Islam dan Budi Pekerti peserta didik. Peningkatan ini nampak pada hasil observasi, pre-test maupun pos test pada tindakan siklus I, dan siklus II. Data perkembangan peningkatan kemampuan komunikasi verbal peserta didik dapat dilihat dari rata-rata keaktifan peserta didik pada masing-masing siklus, yakni dari $16,11 \%$ menjadi $46,67 \%$. Prestasi hasil belajar juga mengalami peningkatan yakni pada siklus 1 rata-rata hasil belajar 74,31 pada siklus 1 menjadi 85,97 pada siklus 2. Persentase ketuntasan belajar juga mengalami peningkatan dari $55,56 \%$ pada siklus 1 menjadi $86,11 \%$ pada siklus II.

Dengan memperhatikan kenyataan adanya peningkatan aktifitas dan prestasi belajar peserta didik dalam proses pembelajaran dengan teknik pembelajaran jigsaw memberi saran kepada para guru khususnya mata pelajaran Pendidikan Agama Islam untuk dapat memilih dan mengembangkan model dan metode pembelajaran yang mendukung keterlibatan peserta didik secara aktif, sehingga pada akhirnya mampu meningkatkan prestasi belajar peserta didik

\section{DAFTAR PUSTAKA}

Alfaris, Afifudin. (2014). Pengaruh Model Pembelajaran Kooperatif Jigsaw Terhadap Prestasi Belajar Menggambar Bentuk Di Sma Negeri 3 Tuban . Jurnal Pendidikan Seni Rupa. Vol 2 No 3.

Aryanti, Risna Dewi. (2015). Perbandingan Penerapan Model Pembelajaran Kooperatif Tipe Jigsaw Dengan Tipe Belajar Bersama (Learning Together) Pada Mata Pelajaran 
Konstruksi Bangunan Kelas X Di Smk Negeri 9 Garut : Penelitian Eksperimen Terhadap Peserta Didik Paket Keahlian Teknik Gambar Bangunan SMK Negeri 9 Garut Semester Genap Tahun Pelajaran 2014/2015. S1 thesis, Universitas Pendidikan Indonesia. From http://repository.upi.edu >

Nabila, Jihan. (2015).Strategi Pembelajaran Berbasis Pendekatan Saintifik. Yogyakarta:Diandra Creative.

Nurhaeni,Y. (2011). Meningkatkan Pemahaman Siswa Pada Konsep Listrik Melalui Pembelajaran Kooperatif Tipe Jigsaw Pada Siswa Kelas IX SMPN 43 Bandung. From http://jurnal.upi.edu > file > 7.

Raka Joni, dkk. (1998). Konsep dasar penelitian tindakan kelas (classroom action research). Jakarta: Departemen Pendidikan Nasional.

Slavin, Robert E. (2011). Cooperative Learning Teori, Riset dan Praktik. Jakarta: Rineka Cipta. . Bandung: Nusa Media.

Sutrisno. (2008). Pendidikan Islam Yang Menghidupkan. Yogyakarta : Kota Kembang.

Vanalita, M., Jalmo, T., Marpaung, R. (2014). Pengaruh Model Pembelajaran Jigsaw Terhadap Kemampuan Komunikasi Lisan Dan Hasil Belajar Siswa. Jurnal Bioterdidik Wahana Ekspresi Ilmiah. Vol 2, No 9. From http://jurnal.fkip.unila.ac.id/index.php/JBT/article/view/6184 